\title{
Az irodalomtanítás válaszai a humán tudományok válságára. Alkalmazott drámapedagógia a klasszikus alkotások tanításában
}

\section{Humán müveltség és irodalomtanítás}

Az 1990-es években egy olyan jelenség narratívája formálódott a teoretikus gondolkodásban, amelynek leglényegibb kérdése a humán tudományok pozíciójának újraértelmezése volt az egyre inkább digitalizálódó, természettudományok által uralt világban. Ez a jelenség nem pusztán filozófiai szempontból volt érdekes, a humán tudományok egészét áthatotta, és olyan intézményesült struktúrákba is beépült, mint az oktatás világa, az általános iskolától kezdve egészen az egyetemekig. Az alakulóban lévő diskurzusnak különböző struktúrák mentén formálódtak a problémafelvetései, filozófiai-teoretikus szinten központi tartalomként jelent meg annak a kérdésköre, hogy a 21. századra miben áll a humán tudományok és a humán műveltség lényege. Az oktatás szintjén az érdeklődés pedig arra irányult, hogy a humán tantárgyak - legfőképp az irodalom és a történelem - hogyan képesek lépést tartani a korral, hogyan kínálhatnak válaszokat a gyerekek számára olyan kihívások kapcsán, amelyek fókusza meglehetősen távol állt azoktól a belső szabályozóktól, melyek mentén hazánkban a tanítás jó ideje körvonalazódott.

Fontos kérdés volt annak a tendenciának a vizsgálata is, miszerint a kultúra soha nem látott tömegekhez jutott el, ${ }^{1}$ tehát nem attól kellett tartani, hogy a kultúrának nincsen „közönsége”, sőt a befogadótábor ugrásszerű növekedése arra irányította a figyelmet, hogy - mint az élet és a tudomány megannyi területén a 20. században - ezen a spektrumon is valamiféle nagy sebességű szétszálazódás veszi kezdetét, és a korábban a tárgyterületen egységesnek és letisztultnak tűnő alapvető fogalmi apparátust kell újból letisztázni, bizonyos esetekben pedig megfosztani a rákövült metaforáktól.

Sok olyan véleménnyel találkozhatunk ekkortájt a tudományos közösségekben, amelyek olykor talán túlságosan is sarkítva fogalmaznak, védelmezve így a féltett

1 Frank Tibor, „A kultúra válsága vagy a válság kultúrája?”, in Éhe a szónak - Irodalom és irodalomtanítás az ezredvégen, PÉTER Ágnes, SARBu Aladár, SzALAY Krisztina, szerk., (Budapest: Eötvös József Könyvkiadó, 1997), 7. 
kategóriába sodródott humán műveltség pozícióját, azonban jó néhány olyan írás is született, melyek igyekeznek mindvégig objektív módon állást foglalni - megfelelő távolságból szemlélni a problémakört -, felvillantva így olyan válaszlehetőségeket, amelyek oldanak a problémakör által felszínre hozott tragikumtudaton.

Bacsó Béla a megértés nyelvi természetére hívja fel a figyelmet, amelyet már a korai hermeneutika kibontakozása kapcsán is megfigyelhetünk. A megértésnek folyamatjellege van, amely kibillenti azt egy statikusnak elgondolt pozícióból, s ez a folyamatjellegű dinamizmus ember és világ között állandóvá válik. Mindez a végső, abszolút megértés örökös hiányát is jelenti, sokak pedig ezt a megérthetetlenséget egyfajta krízishelyzetként definiálják. Bacsó Béla szerint a kialakult krízishelyzetre akkor adhatunk kielégítő, a problémát megoldani képes választ, ha arra az elvárás horizontjából tekintünk. Ebben a felfogásban pedig nem a humán tudományok nyújtanak immár keveset az ember számára, sokkal inkább az elvárás nőtt meg feléjük túlságosan is. ${ }^{2}$ Nem képesek filozófiai-ontológiai igazságtételre, az egészlegesség és az abszolút értés látszatának fenntartására úgy, ha a világ eleve valamiféle szétszálazódott paradigma mentén artikulálódik. A humán tudományok ebben a helyzetben annyit tehetnek, hogy lehetőséget villantanak fel az ember számára. A szétszálazódott, meg nem érthető világban az orientálódás lehetőségét. Abban az esetben, ha erre a humán tudományok nem válnak képessé, és örökös lemaradásban csupán valamiféle kompenzációs jelleggel bírnak, „halálra vannak ítélve”. ${ }^{3}$ Feladatuk nem az, hogy saját terepén vegyék fel a versenyt a természettudománnyal, sokkal inkább arra kell törekedniük, hogy a természettudományok által technikalizált világot berendezzék, otthonossá tegyék. Ez pedig csak és kizárólag úgy lehetséges, ha nem mindig csupán előre tekintenek, hanem folyamatosan reflektálnak önmagukra és az eddigi tradícióikra, amely reflektív képesség lényegi sajátjuknak tekinthető. Így legfőbb feladatuk egyfajta örökös „hermeneutikai” kérdezés, a „perspektivizmus megkérdőjelezése”. ${ }^{4}$

Mások úgy vélték, élesen el kell különítenünk egymástól olyan fogalmakat, amelyek sokszor összemosódtak, mint például a humán múveltség és a humán tudomány. Bókay Antal a humán műveltség fogalmát egy átfogóbb diskurzusrendszerbe próbálja helyezni, a humán műveltséget már egy bizonyos kultúra „önreflexív leképeződéseként” értelmezi, a legfontosabb kérdése pedig az, hogy ez a humán

\footnotetext{
2 BAcsó Béla, „A humán tudományok válsága: szempontok a problémához”, in Éhe a szónak - Irodalom és irodalomtanitás az ezredvégen, PÉTER Ágnes, SARBu Aladár, Szalay Krisztina, szerk., (Budapest: Eötvös József Könyvkiadó, 1997), 204-205.

3 Uo., 205.

4 Uo., 206.

5 BóKAY Antal, „Posztmodern alternatíva a kultúra és az irodalom olvasásában. Humán műveltség, nyelv, posztmodern", in Éhe a szónak - Irodalom és irodalomtanitás az ezredvégen, PÉTER Ágnes, SARBU Aladár, SzALAy Krisztina, szerk., (Budapest: Eötvös József Könyvkiadó, 1997), 188.
} 
műveltség - amelyre metakultúraként tekint, amennyiben az akkor jön létre, mikor valamilyen kultúra erőteljesen meggyengül, és szükség van annak intézményesült, fogalmakban rögzített kialakítására - milyen mértékben nélkülözhetetlen. Az ő felfogásában a humán műveltség válsága egyenlő a humán tudományok válságával, „a metanarratívaként értelmezett kultúra sem racionális, sem tradicionális alapon nem védhető". ${ }^{6}$ Ezzel szembe helyezi a posztmodern műveltségfogalmat, amely „magát a műveltség fogalmát vonja kétségbe; a mûveltség fogalmán belül és azzal szemben egyre nagyobb szerepet kap az önélvezet, a vágyartikuláció fogalma, melyben a kultúra hermeneutikaivá, a befogadás eseményében teremtődővé, lehetőséggé, vagyis jövővé válik" ${ }^{7}$

Nem lepődhetünk meg azon, hogy a humán műveltség felé intézett fontos kérdések nem pusztán az akadémikus szférában tartottak számot érdeklődésre, rávetültek az oktatási rendszerekre és folyamatokra is, hiszen a kultúraátörökítés és a kultúraképzés egyik legfontosabb hagyományos színtere maga az iskola. ${ }^{8}$

Talán Közép-Kelet-Európában azért volt szükség a problémakör még árnyaltabb szemlélésére, mivel a rendszerváltást megelőző politikai berendezkedés teljesen más irányt szabott a tárgyterület alakulástörténetének az életnek ezen terültén is. ${ }^{9}$ Különösen igaz volt ez az egyetemekre nézve, ahol többek között a humán tudományok is megsínylették a rendszerváltás előtti uralkodó ideológiai narratíva kizárólagosságát. A rendszerváltást követő évek a gondolkodásnak egy olyan szisztémáját hozták felszínre, amelyben a korábbi tudás értéktelennek, kevésbé értékesnek bizonyult. Az értelmiségiek képzésének tehát át kellett alakulnia, illetve olyan értelmiségre volt szükség, amely ellentmondott a régi, az értelmiségivel kapcsolatos rendszerváltást megelőző elképzeléseknek, miszerint az ilyen embernek metafizikusnak és érdek nélkülinek kell lennie. Olyan - a közoktatásban is - fontos további kérdések jelentek meg továbbá az egyetemek szintjén, mint például a humán tudományok természettudományokkal szembeni haszontalanságának gondolata vagy az oktatási menedzsmentkrízis kérdésköre. ${ }^{10}$

Számos olyan probléma is generálódott, amelyek tágabb értelemben voltak érvényesek az egész közoktatás területére a humán múveltség kapcsán, és ezekre olyan tudományos válaszok érkeztek, amelyek a mai napig meghatározók, és amelyek elkezdték kijelölni egy modern, nyugati léptékủ struktúra kiépülésének központi jellemzőit.

\footnotetext{
6 Uo., 189.

7 Uo., 189

8 SÁsKa Géza, Kultúra az iskolában (jegyzet), (Educatio, 2004/2), 285.

9 BACSó, i. m., 207.

10 ABÁDI NAGY Zoltán, „A humán tudományok válságának kérdése a felsőoktatás-menedzsment szemszögéből”, in Éhe a szónak - Irodalom és irodalomtanítás az ezredvégen, PÉTER Ágnes, SARBU Aladár, SzAlAY Krisztina, szerk., (Budapest: Eötvös József Könyvkiadó, 1997), 210-226.
} 
Az egyik legfontosabb egy pragmatikus jellegű, a gyakorlati életre felkészítő, legtöbbször az adott társadalom indusztriális szférája által meghatározott, valamint egy a - hazánkban évszázados hagyományoknak örvendő - kultúraátadást előtérbe helyező, klasszikus értékeket közvetítő, az etikai perspektívát preferáló nevelési-oktatási rendszer szembeállítása volt. A nyugati mintákban a tudás új típusú szemléletével találkozhatunk, amelyben a procedurális jelleg a domináns, azaz a deklaratív jellegủ tudással szemben - amely az ismeretekre helyezi a legnagyobb hangsúlyt - itt a képesség kerül fókuszba. ${ }^{11}$ Innen nézve lényegesen megváltozik az iskola hazánkban hagyományos feladatköre, hiszen a „pszichológiailag meghatározott kompetenciát, a kultúra perspektívájából értelmezhető műveltséget, és a szakterület által meghatározott szakértelmet”12 is fejlesztenie kell. Ebben az értelmezésben is láthatjuk, hogy a hagyományos iskolai szerepkör átértékelődik, és az etikai-morális alapvetésű nevelési-oktatási folyamat mindinkább egy olyan irányba mozdul el, amelynek elkerülhetetlenül egyfajta gazdaságpolitikai felhajtóereje van, és nem a társadalom számára erkölcsileg-ideológiailag megmunkált in dividuumok képzése lesz az elsődleges feladata, hanem olyan „fogaskerekek” előállítása, amelyek zavartalanul illeszkednek bele abba a nagy gépezetbe, amely az adott - nemzeti közösségeken átívelő globális piac számára aktuálisan a leginkább képes hasznot hozni. Így az oktatási folyamat valamiféle utilitárius jelleget ölt.

Mindez persze erőteljesen érintette a humán tantárgyak világát is, új irányokat jelölve ki így az irodalomoktatásban, amely egy érvényét vesztett kultúrafogalomból indult ki, és továbbra is azokat a tanulókat tartotta a leginkább múveltnek, akik a legnagyobb - alapvető műveltséget feltételező - lexikai tudásbázissal rendelkeztek. Az egész irodalompedagógiát áthatotta egyfajta maximalizált tudásnak az ábrándja, amely nem pusztán elméleti síkon volt jelen, de determinálta a tantervi szabályozó dokumentumok alakulását is. Ezen felül komoly figyelmet kellett fordítani a pedagógusok nézeteire és irodalompedagógiai felfogására, ugyanis sokan közülük helytelenül értelmezték annak a váltásnak a lehetőségét, amelyet a rendszerváltás utáni tartalmi, formai és módszertani szabadság lehetővé tett volna számukra. Hiszen számos esetben nem a tantárgy-filozófiai alapokból kiindulva gondolkodtak el a változtatás lehetőségén, bizonytalanok és bizalmatlanok voltak a kortárs irodalomtudományi és irodalompedagógiai kutatások területén, így az átalakulás olyan irányban ment végbe, amely meghagyta ugyan a „demokratikus óratervezés"13 látszatát, de az interpretációs folyamatban a naiv olvasatok megsokasodását

11 CsAPó Benő, KÁRPÁTI Andrea, „Mưveltség az ezredforduló után - Az oktatás fejlesztésének feladatai", in Az iskolai múveltség, Csapó Benő, szerk., (Budapest: Osiris Kiadó, 2002), 299-313.

12 Uo., 300.

13 Sipos Lajos, „Új törekvések a humán tárgyak tanításában”, Iskolakultúra, 2. sz., (2002): 85. 
eredményezte. ${ }^{14}$ Nehéz helyzetbe kerültek tehát a pedagógusok is, akik eddig a nagy, közös tudás birtokosaiként és átadóiként határozhatták meg önmagukat, most azonban az elvárások alapján le kellett mondaniuk erről a szerepkörről, és olyan individuumokká kellett válniuk, akik sokkal inkább a facilitátor és a tutor fogalma felől értelmezhetők. ${ }^{15}$

Annak ellenére, hogy a régi típusú iskolamodell megkérdőjeleződött, és a tanárok szerepköre gyökeresen megváltozott, a pedagógusoknak mégis központi pozíciójuk maradt, hiszen az értelmezési folyamatban, továbbra is kulcsfontosságú faladatuk volt. Nagyrészt az ő „intellektusuk hordozta” a tananyag „újraértelmezésének lehetőségét," ${ }^{16}$ amely továbbra is az egyik legfontosabb kategóriája volt az iskolai műveltség hordozóinak. ${ }^{17}$

Számos további tényező került felszínre, amelyek elkezdték lebontani a hagyományos irodalomtanítási paradigmát, és új irányokat szabtak ki az irodalompedagógia egészében. Arató László már ekkor hangsúlyozta az irodalmi hermeneutika és az irodalomtanítás viszonyának elsődlegességét, a megértés részlegességét, az interpretációk körének történetileg változó voltát, a jelentésképzés nyitottságát, egy kreatívabb irodalomtanítási rendszer szükségességét, amely elsődlegesen a kritikai érzékeket fejleszti. Mindemellett pedig nagy figyelmet szentelt a tanítási folyamatban a medialitásnak (pl. reklámok és klipek) és a popkultúra bizonyos elemeinek, amelyek egyfajta ajtóként funkcionálhatnak a megértési folyamatban, és lehetővé tehetik a szépirodalmi műalkotások világában való lényegi esztétikai elmélyülést is. ${ }^{18}$

Az irodalomtanításnak egy olyan újszerú paradigmája volt tehát kialakulóban, amely a humán tantárgyak esetében is a nevelési-oktatási folyamat egyik központi céljává kívánta tenni az alapvető tanulói készségek és képességek folyamatos fejlesztését. Mindez persze nem jelentette azt, hogy nem szükséges a tantárgyi tudás, ugyanis a „kultúrába való beágyazódás nem lehetséges a kultúra alaptörténeteinek elsajátítása nélkül”. ${ }^{19}$

14 Vö. NAHALKA István, Hogyan alakul ki a tudás a gyerekben? Konstruktivizmus és pedagógia, (Budapest: Nemzeti Tankönyvkiadó, 2002).

15 Vö. Czeizer Zoltán, „A digitális forradalom és a magyar oktatás”, Educatio, 4. sz., (2002): 623-628. https://folyoiratok.oh.gov.hu/sites/default/files/article_attachments/czeizer_z_2002_04.pdf (Letöltés ideje: 2021. 08. 18.)

16 Csoma Gyula, A kivánatos müveltség dilemmái a közoktatásban, Educatio, 2. sz., (2004): 251.

17 Uo., 251

18 ARATó László, „Felvonók az elefántcsonttoronyhoz”, in Éhe a szónak - Irodalom és irodalomtaní tás az ezredvégen, PÉTER Ágnes, SARBu Aladár, SzAlay Krisztina, szerk., (Budapest: Eötvös József Könyvkiadó, 1997), 262-267.

19 CSAPó KÁRPÁTI, i. m., 309. 


\section{Kultúraörökítő és/vagy pragmatikus jelleg}

Az ezen kérdéskör körül létrejövő viták két szélsőséges nézetet is generáltak az irodalomtanítás kapcsán, amely nézetek a mai napig politikai narratívák részeit is képzik, ha irodalompedagógiáról vagy annak jövőjéről van szó a közbeszédben. Az egyik ilyen elgondolás továbbra is a tradicionalista megközelítésmód elsődlegességét hirdeti, az irodalomtanítás legfőbb feladatát a kultúraközvetítésben, illetve a legfontosabb morális alapelvek átadásában látja, amelyek a közoktatásban eltöltött évek alatt megszilárdulnak a gyerekekben, ezeket az alapvető értékeket a gyerek pedig a társadalom jól funkcionáló tagjaként tudja majd képviselni, így nem pusztán ő, de általa a társadalom is etikailag ,jobbá” lényegül. Ha történeti szempontból vizsgáljuk hazánk oktatási struktúráit, mindenképp azt mondhatjuk, ennek a meglátásnak van leginkább hagyománya nálunk.

A másik elgondolás az irodalomoktatás lényegét nem elsősorban a kultúraátadásban és a lexikális ismeretanyag felhalmozásában látja, hanem a tanítási folyamatok központi elemeit egyfajta pragmatikus irányelv mentén képzeli el, vagyis azt tartja az irodalomtanítás egyik központi feladatának, hogy olyan képességeket, készségeket fejlesszen, amely a gyerekek boldogulását segíti elő az átalakult világban. Ez a modell sokkal inkább egy globális-gazdasági paradigma felől értelmezhető, nem pedig a nemzeti-kulturális perspektíva felől, mint az előbbi. További fontos különbség a kettő között, hogy míg a kultúraátadó modellben inkább a pedagóguson van a hangsúly, aki egyfajta médiumként közvetíti a tudást, addig a pragmatikus modellben a gyerek lesz a középpontban, illetve azok a belső folyamatok, amelyek a tanulás, esetünkben pedig fókuszáltan az irodalomértés, az irodalommal való találkozás közben lejátszódnak.

A közbeszédben sajnos sokszor hallhatunk arról, hogy politikai narratívák mentén egyik vagy másik kizárólagosságát hirdetik, ugyanakkor az én véleményem és a szúkebb értelemben vett irodalompedagógiai szakma meglátása szerint egyik nem zárja ki a másikat, csupán hangsúlyeltolódásról beszélhetünk egyik vagy másik javára. Az oktatási rendszer bonyolultsága és az évszázados hagyomány ellehetetleníti azt, hogy egyik napról a másikra óriási horderejû változások következzenek be a tárgyterületen, ráadásul a nevelési-oktatási folyamatban bárminemû́ pozitív változások csak igen hosszú idő után érezhetők és mérhetők. Így tulajdonképpen az volna a kívánatos, ha ez a hangsúlyeltolódás apránként a pragmatikus irányba megtörténne, ugyanakkor továbbra is fontos volna a kulturális paradigma, de nem akkora hangsúllyal és nem abban a formában, miképpen ma ezzel találkozhatunk.

Ebben az esetben nagyon fontos rákérdeznünk arra, miképpen tehetnénk izgalmasabbá, élvezetesebbé, befogadó-központúvá a klasszikus világirodalom és a régi magyar irodalom szövegeit, témáit és formáit a gyerekek számára. Hiszen számos olyan tényező van, ami megnehezíti a szövegfeldolgozásokat és a befogadást. 
Ilyen például a történeti távolság, ami egyfajta nyelvi távolság is. Azok az archaikus szövegelemek és azok a narratívák, amelyek az adott kor szereplői számára teljesen világosak voltak, a mai iskolásoknak komoly nehézséget okoznak. A művek nagy része tartalmi és formai szempontból is akadályokat állít az interpretáció folyamatába.

Úgy gondolom, az egyik nagyon jó megoldás erre a problémára az lehetne, ha a kortárs vagy modern szövegek felől próbálnánk nyitni a klasszikusok felé, tematikus rendszerben gondolkodva. Ugyanakkor számos olyan módszertani lehetőség is adódik, amelyek színesebbé tehetik az ilyen régi szövegek tanítását is, izgalmassá téve a tanórákat. Ilyen izgalmas eszközként tekintek a drámapedagógiára mint módszertani apparátusra.

\section{Alkalmazott drámajátékok és klasszikus szövegek}

Magyarországon a tanulásszervezési módok közül sajnos még mindig a frontális osztálymunka az elsődleges, amelyről ugyan tudjuk, hogy bármely tanulásszervezési stratégia alkalmazása esetén bizonyos szempontból megkerülhetetlen, ugyanakkor a legfőbb kérdés mégiscsak az, hogy melyik modell milyen súllyal van jelen az oktatásban, és úgy gondolom, egy modern oktatási rendszernek mindenképp a gyerekközpontú elgondolások felé kellene mozdulnia, mint például a kooperatív tanulásszervezés vagy a projektmódszer.

A frontális osztálymunka - amelynek egyébként számos előnye van, melyeket itt nem kívánok részletezni - egyik legnagyobb hátránya az, hogy elsődlegesen a pedagógusra épít, őt helyezi a tanóra középpontjába, a gyerekek pedig sajnos nagyon sokszor a teljes passzivitás irányába tolódnak. Az órák sok esetben előadásjellegűvé válnak, kiegészülve néhány irányított tanári kérdéssel, amelyekre többnyire ugyanazok a gyerekek felelnek majd. Úgy vélem, hosszú távon, a majdani felnőtt életre vonatkoztatva is komoly gondot okozhat, ha a gyerekek belesüppednek a passzív szerepbe, megszokják azt, hogy az ő elgondolásaik, az ő szavuk nem számít (gondolok itt az irodalompedagógiai kapcsán elsősorban arra, mikor a tanár jelentéskánonokat tanít, a tanulói interpretációt nagyrészt kirekesztve az óráról).

Ezzel szemben a kooperatív tanulásszervezési forma és a jól eltervezett és kivitelezett projektmódszer legnagyobb előnyének azt tartom, hogy a frontálissal szemben itt a gyerekeken és az aktív tanulási folyamatokon van a hangsúly, a tanár pedig egyfajta iránymutatóként, mellérendelt segítőtársként, facilitátorként, tutorként dolgozik a tanulókkal, a tanulókért. Noha ezen tanulásszervezési formákat is lehetséges rosszul szervezni és kivitelezni, gyermekközpontú filozófiájuk sokkal közelebb visz minket egy olyan irodalompedagógiához, amely hermeneutikai alapokon áll és modern.

A drámapedagógiára nem mint tanulásszervezési formára tekintek, hanem sokkal inkább mint egyfajta módszertani apparátusra, amely mindhárom említett 
paradigmában jól tud funkcionálni. Ha alapvetően frontálisan képzelünk el egy tanítási órát, alkalmazott drámajátékok bevonásával sokkal színesebbé, a gyerekek számára is sokkal élvezetesebbé tehetjük azt.

A drámapedagógiának három olyan tartópillére - tudományos bázisa - van, amelyből táplálkozik, amely tudományterületek hozzájárultak ahhoz, hogy elnyerhesse mai formáit, amelyek folyamatosan alakulnak még most is (mivel fiatal tudomány, jó néhány kiforratlan részterülettel, bizonytalan terminológiával találkozhatunk). Ez a három terület a színház, a pedagógia és a pszichológia, ${ }^{20}$ amely három fogalom közül számunkra a pedagógia lesz a legfontosabb.

A drámapedagógia mai formájának gyökerei a 19. század második feléig nyúlnak vissza, John Deweyhoz, akinek az iskolával kapcsolatos modern elgondolásait (az iskola képezze le a társadalmi teret, a társadalmi világ makrokozmoszának mikrokozmoszaként funkcionáljon az iskola intézménye stb. $)^{21}$ számos reformpedagógiai irányzat, illetve a drámapedagógia is hasznosította. A legfontosabb ezek közül a drámapedagógiára vonatkoztatva, hogy a gyerekek tudatosan és aktívan vegyenek részt saját tanulói folyamatukban, amely közben folyamatosan ismerjék meg identitásukat, társaik identitását is, ezáltal pedig fejlődjenek különböző képességterületeik.

A drámapedagógiai módszerek nagyon jól beépíthetők a konstruktivista paradigma mentén az irodalompedagógiába. A konstruktivizmus leglényegesebb óratervezésre vonatkozó modellje az RJR-modell, azaz a tanórák a ráhangolódás, jelentésteremtés, reflexió hármas kategóriarendszere mentén épülnek fel.

A következőkben pedig nézzünk meg néhány alkalmazott drámajátékot, amelyek illeszkedhetnek az RJR-modell bizonyos szakaszaihoz, illetve a klasszikus irodalmi alkotások tanítása kapcsán is működhetnek.

Érzelmi asszociáció: Ez a játék az óra mindhárom szakaszában alkalmazható. Ha a gyerekek az előző órán megismerkedtek már az aktuális szerző valamely alkotásával, a ráhangoló fázisban - amikor az előzetes ismeretek mozgósítása az egyik fő cél -, ha éppen azon az órán találkoznak egy alkotással, akkor pedig a jelentésteremtés vagy a reflexió szakaszában alkalmazhatjuk. A játék lényege, hogy a tanulók kifejezzék azokat az érzelmeket, amelyek megfogalmazódtak bennük az adott mű kapcsán. Ugyanakkor mindezt nem verbális formában kell megtenniük. Választaniuk kell egyet az érzelmek közül, ami a leginkább hangsúlyos, ezt pedig nonverbális formában el kell játszaniuk (gesztusokkal, mimikával), a többi tanulónak pedig ki kell találnia, hogy mi lehet az adott érzelem.

20 Vö. PInCZÉSNÉ PALÁsthy Ildikó, Dráma, pedagógia, pszichológia, (Debrecen: Pedellus Tankönyvkiadó, 2003).

21 Vö. John Dewey, A nevelés jellege és folyamata, ford. MolnÁr Magda (Budapest:Tankönyvkiadó, 1976). 
Állókép:Ez a játék versek esetében is müködhet, de olyan müvek esetében is, amelyek narratív struktúrával rendelkeznek. Lényege, hogy a tanár kiválaszt néhány tanulót, majd felolvas az adott múből egy rövid részletet. A kiválasztott tanulóknak pedig az a feladatuk, hogy rövid megbeszélés után olyan pozíciót vegyenek fel, amely kirajzolja azt a képet, amelyet a felolvasott részlet indukált bennük. Líra esetében ez természetesen teljes mértékig szubjektív, ugyanakkor egy epikai vagy drámai alkotás kapcsán konkrétabb is lehet. Azért, hogy senki se maradjon ki a játékból, a tanár csoportokra bonthatja az osztályt, és minden csoportnak felolvashat egy-egy részletet. Ez a játék leginkább a ráhangolódás és a reflexió szakaszában működhet, a játék végeztével lehet arról beszélgetni a diákokkal, hogy vajon miért éppen ezek a jelenetek voltak kiemelve, miért lehetnek ezek fontosak az adott szövegekben.

Képzeletbeli történetlánc:Szintén a ráhangolódás vagy a reflexió fázisában müködhet leginkább, olyan szövegek esetén, amelyeknek van szereplője. A játék lényege ugyanis az, hogy tovább kell gondolni a müben megjelenő valamely karakter sorsát. A tanár vagy a diákok kiválasztanak egy szereplőt a szövegből. Olyan is lehet, aki fontos a mű szempontjából, de az is izgalmas, ha mellékszereplőt választanak. A tanár felszólít egy diákot, akinek mondania kell egy mondatot a választott szereplőhöz igazodva úgy, hogy az ne legyen ismert a történetből, aztán a többi diák is hozzátesz egy-egy mondatot ehhez a képzeletbeli történethez, amely feltárhatja az alkotás valamely karakterének előtörténetét vagy utóéletét. A játékot úgy is lehet játszani, hogy a gyerekek sorban haladnak, mindig az aktuális mesélő mellett ülő diák mondja a következő mondatot, illetve úgy is, hogy aki a következőt szeretné mondani, jelentkezik. A lényeg, hogy minden tanuló vegyen részt ebben a történetszövésben, amely egyrészt fejleszti a kreativitást és a kommunikációs készségeket, másrészt pedig általa megmerítkezhetünk a műalkotás világában.

Cselekvés másképp: A játék drámák vagy epikai alkotások esetében alkalmazható sikeresen. A diákok közül valaki önként jelentkezik, vagy a tanár kiválaszt közülük valakit, majd az osztálynak felolvas a műből egy olyan részletet, amelyben hangsúlyosan valamilyen cselekmény kerül előtérbe. A választott diák feladata az lesz, hogy játssza el a cselekvést, de ne úgy, ahogy az eredetileg benne van a szövegben, hanem akképpen, ahogy ő cselekedne az adott szituációban. Miután a diák eljátszotta a saját döntése által megváltoztatott jelenetet, a többi diáknak arról kell megnyilatkoznia, hogy ez a megváltozott cselekvés milyen irányban változtathatta volna meg az egész műalkotás világát az eredeti verzióhoz képest.

Történet modern köntösben: A tanár vagy a gyerekek egy drámai müből választanak egy részletet, amelyet úgy adnak elő, mintha mai, modern kontextusban játszódna. Figyelniük kell arra is, hogy az előadás nyelvezete is modern legyen, olyan 
szófordulatokkal, szlengekkel, amelyek igazodnak napjaink nyelvhasználatához. A jelentet eljátszása után az osztállyal érdekes lehet annak a megvitatása, hogy a műalkotás által feltett kérdések milyen formában vannak jelen a mai korban, illetve ma milyen válaszokat tudnának rájuk adni.

\begin{abstract}
The state of human sciences has changed around the end of 20th century. It was an autentic process what included an philosophical transformation which influenced the system of education. The one of the most important questions in literature teaching in Hungary was the transfer of national cultural knowledge and instruction of the basic ethical rules for the students, but the mentioned problem had been createing a new, pragmatic and modern method in the literature teaching. The new model oriented to ideas which were already general in the more developed westward pedagogics, for instance hermeneutics attitudes in the interpretation, the priority of the student's identity and adaptation of diverse teaching methods. I consider, the more colorful methods and exercises like drama in education can give a lot of experience for the children therefore they are able to read and interpret the classical texts and the modern literature as well, so they can become reading people.
\end{abstract}

